\title{
Cytotoxicity of Reparative Endodontic Cements on Human Periodontal Ligament Stem Cells
}

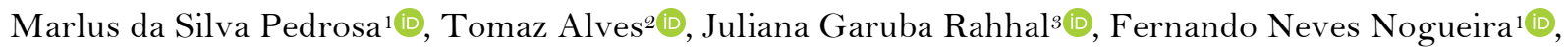 \\ Carla Renata Sipert ${ }^{3}$ (D)
}

\begin{abstract}
${ }^{1}$ Department of Biomaterials and Oral Biology, School of Dentistry, University of São Paulo, São Paulo, SP, Brazil.
${ }^{2}$ Department of Stomatology, School of Dentistry, University of São Paulo, São Paulo, SP, Brazil.

${ }^{3}$ Department of Restorative Dentistry, School of Dentistry, University of São Paulo, São Paulo, SP, Brazil.
\end{abstract}

Correspondence: Prof. Carla Sipert, Departamento de Dentística, Faculdade de Odontologia, Universidade de São Paulo (USP). Av. Prof. Lineu Prestes 2227, São Paulo, SP, Brazil. 05508-900. E-mail: sipert@,usp.br

Academic Editor: Myroslav Goncharuk-Khomyn

Received: 05 June 2021 / Review: 28 July 2021 / Accepted: 13 September 2021

How to cite: Pedrosa MS, Alves T, Rahhal JG, Nogueira FN, Sipert CR. Cytotoxicity of reparative endodontic cements on human periodontal ligament stem cells. Pesqui Bras Odontopediatria Clín Integr. 2022; 22:e210114. https://doi.org/10.1590/pboci.2022.004

\begin{abstract}
Objective: To compare the cytotoxicity of commercial reparative endodontic cements on human periodontal ligament stem cells (hPDLSCs). Material and Methods: The culture of hPDLSCs was established. Cell density was set at $2 \times 10^{4}$ cells/well in 96-well plates. Extracts of Biodentine, Bio-C Repair, Cimmo HD, MTA Repair HP and White MTA were prepared. Then, the extracts were diluted (pure, 1:4 and 1:16) and inserted into cell-seeded wells for 24, 48, and $72 \mathrm{~h}$ to assess cell viability through MTT assay. hPDLSCs incubated with culture medium alone served as a negative control group. Data were analyzed by Two-Way ANOVA and Tukey's test $(\alpha=0.05)$. Results: At 24 h, pure extract of MTA Repair HP and Biodentine 1:16 presented higher cell viability compared to control. Lower cell viability was found for pure extract of Cimmo HD, MTA Repair HP 1:4 and 1:16, and White MTA 1:16. At 48 h, pure extract of Bio-C Repair and MTA Repair HP presented higher cell viability compared to control. At $72 \mathrm{~h}$, only the pure extract of MTA Repair HP led to higher cell proliferation compared to control. Conclusion: Biodentine, Bio-C Repair and MTA Repair HP were able to induce hPDLSCs proliferation. Cimmo HD and White MTA were found to be mostly cytotoxic in hPDLSCs.
\end{abstract}

Keywords: Endodontics; Dental Cements; Periodontal Ligament; Cytotoxicity Tests, Immunologic. 


\section{Introduction}

Calcium silicate-based cements (CBSC) have received a lot of interest from endodontists due to their biocompatibility and bioactivity. As a result, these materials have been indicated in root-end filling, pulp capping, pulpotomy, apexogenesis, apexification and in cases of root perforation, retro filling, direct pulp protection, restoration of deciduous tooth and cavities with enamel without dental support (dentine substitute) and non-conventional endodontic treatment without gutta-percha [1-13].

Mineral trioxide aggregate (MTA) is CBSC extensively used in endodontics [1,2]. However, MTA presents some drawbacks such as long setting time, inducement of tooth discoloration and difficult handling $[3,4]$. To overcome it, several new bioactive endodontic cements have been introduced to the market. Among these materials are Biodentine (Septodont, Saint-Maur-des-Fossés, France), Bio-C Repair (Angelus Indústria de Produtos Odontológicos S/A, Londrina, PR, and Brazil), Cimmo HD (PBS Cimmo Soluções em Saúde, Pouso Alegre, MG, Brazil) and MTA Repair (Angelus Indústria de Produtos Odontológicos S/A, Londrina, PR, Brazil).

Biodentine is CSBC presented in powder and liquid system [5-7]. Biodentine presents good sealing ability, favorable biological and physical properties, increased biocompatibility and a wide range of clinical applications [8]. Bio-C Repair is a ready-for-use CSBC [9-11]. According to the manufacturer, besides presenting the same indications of conventional MTA, Bio-C Repair is easy to be applied and does not contribute to discoloration, acts as a barrier against microorganisms, and stimulates tissue healing.

MTA Repair HP is based on the chemical formulation of conventional MTA but with improved physical properties related [12]. It is composed of a powder and a mixing liquid with a plasticizer agent. The bismuth oxide radiopacifier in the conventional MTA was replaced for calcium tungstate in the MTA Repair $[12,13]$. Cimmo HD is a biological cement developed with the same base as MTA or Biodentine, but with natural elements as additives to increase the cement resistance and without radiopacifier [14].

The biological properties of new endodontic materials should be assessed to minimize adverse effects [15]. In vitro cytotoxicity tests are used to detect toxic effects caused by material or its extract in cell culture [12]. Therefore, this study was conducted to assess the in vitro toxicity of Biodentine, Bio-C Repair, Cimmo HD, MTA Repair HP and White MTA. The null hypothesis tested was that the calcium silicate-based cements would present a similar effect on the cell viability.

\section{Material and Methods}

Primary Culture of hPDLSCs

The experimental protocol was approved by the Ethics Committee of the School of Dentistry of the University of São Paulo (Protocol\# 3.895.056). The hPDLSCs were obtained from the cell biobank of the School of Dentistry of the University of São Paulo and cultured in Minimum Essential Medium $\alpha(\alpha-M E M)$ (Invitrogen, Thermo Fisher Scientific, Waltham, MA, USA) with 10\% fetal bovine serum (FBS) (Gibco, Thermo Fisher Scientific, Waltham, MA, USA), $100 \mu \mathrm{g} / \mathrm{mL}$ penicillin, $100 \mu \mathrm{g} / \mathrm{mL}$ streptomycin, and 0.5 $\mathrm{mg} / \mathrm{mL}$ amphotericin $\mathrm{B}$ at standard culture conditions $\left(37^{\circ} \mathrm{C}, 100 \%\right.$ humidity, $5 \% \mathrm{CO} 2$ and $95 \%$ air $)$ [16]. hPDLSCs cells from passages four to eight were used for MTT Assays. hPDLSCs cells were seeded at $2 \times 10^{4}$ cells per well.

\section{Characterization of hPDLSCs}


The characterization of hPDLSCs was performed by immunostaining and evaluated by flow cytometry. The cells were seeded at $5 \times 10^{5}$ concentration and incubated in $5 \% \mathrm{FBS} / \mathrm{PBS} 1 \mathrm{x}$ at $4{ }^{\circ} \mathrm{C}$ in the dark for 1 hour with OCT4-FITC, SOX2-FITC, STRO-1-FITC (Abcam, Cambridge, UK), CD90-FITC (eBioscience, San Diego, CA, USA), CD34-FITC (Biolegend, San Diego, CA, USA), CD31-PE, CD-44-PE (eBioscience, San Diego, CA, USA) and CD146-PE (Biolegend, San Diego, CA, USA) antibodies for 30 min at $4{ }^{\circ} \mathrm{C}$. Unstained control was used to set gates. A total of 10-50,000 events were recorded and data analyzed in FlowJo software (Becton, Dickinson and Company, Franklin Lakes, New Jersey, USA) [16].

Specimen and Extract Preparation

All materials (Table 1) were manipulated according to the manufacturers' instructions and were inserted into a round metal appliance designed for the production of discs measuring $5 \mathrm{~mm}$ wide and $3 \mathrm{~mm}$ high. Materials were allowed to set for $24 \mathrm{~h}$ in a humid atmosphere and aseptic conditions. After setting, each specimen was immersed into $1 \mathrm{~mL}$ of $\alpha$-MEM with $10 \% \mathrm{FBS}$ and incubated for $72 \mathrm{~h}$. The specimens were then discarded and the pure extracts were filtered by $0.22-\mu \mathrm{m}$ pore size membranes (Millipore; Billerica, MA, USA) $[17,18]$.

Table 1. Tested materials.

\begin{tabular}{|c|c|c|c|}
\hline Materials & Manufacturer & Composition & Proportion \\
\hline Biodentine & Septodont, France. & $\begin{array}{l}\text { Powder: Tricalcium silicate, zirconium } \\
\text { oxide, calcium oxide, calcium carbonate, } \\
\text { brown pigment, red pigment and brown } \\
\text { iron oxide } \\
\text { Liquid: dehydrated calcium chloride } \\
\text { and purified water }\end{array}$ & $\begin{array}{l}\text { Five drops of the liquid for } \\
\text { one capsule }\end{array}$ \\
\hline Bio-C Repair & $\begin{array}{l}\text { Angelus Indústria de } \\
\text { Produtos Odontológicos } \\
\text { S/A, Londrina, PR, Brazil }\end{array}$ & $\begin{array}{l}\text { Calcium silicate, calcium oxide, zirconium } \\
\text { oxide, iron oxide, silicon dioxide, dispersing } \\
\text { agent }\end{array}$ & Ready to use \\
\hline Cimmo HD & $\begin{array}{l}\text { Cimmo Soluções em } \\
\text { Saúde, Pouso Alegre, } \\
\text { MG, Brazil }\end{array}$ & $\begin{array}{l}\text { calcium oxide, calcium carbonate, } \\
\text { magnesium oxide, dicalcium silicate, } \\
\text { aluminum oxide, sodium oxide, potassium } \\
\text { oxide and pozzolan }\end{array}$ & $\begin{array}{l}1 \text { blister for and } 1 \text { drop of } \\
\text { the liquid. }\end{array}$ \\
\hline MTA Repair & $\begin{array}{l}\text { Angelus Indústria de } \\
\text { Produtos Odontológicos } \\
\text { S/A, Londrina, PR, Brazil }\end{array}$ & $\begin{array}{l}\text { Powder: Tricalcium silicate, dicalcium } \\
\text { silicate, tricalcium aluminate, calcium oxide } \\
\text { and calcium tungstate } \\
\text { Liquid: Water and plasticizer }\end{array}$ & $\begin{array}{l}1 \text { package of MTA Repair } \\
\text { HP for } 2 \text { drops of the } \\
\text { liquid. }\end{array}$ \\
\hline White MTA ${ }^{\circledR}$ & $\begin{array}{l}\text { Angelus Indústria de } \\
\text { Produtos Odontológicos } \\
\text { S/A, Londrina, PR, Brazil }\end{array}$ & $\begin{array}{l}\text { Powder: Tricalcium silicate, dicalcium } \\
\text { silicate, tricalcium aluminate, calcium oxide, } \\
\text { bismuth oxide Liquid: Distilled water }\end{array}$ & $\begin{array}{l}1 \text { sachet of White MTA for } \\
1 \text { drop of distilled water. }\end{array}$ \\
\hline
\end{tabular}

Cell Stimulation with Materials Extracts

The pure extracts (1) were diluted (1:4 and 1:16) in $\alpha$-MEM supplemented with $10 \% \mathrm{FBS}$. hPDLSCs were counted and seeded at $2 \times 10^{4}$ cells/well in 96-well plates in $\alpha$-MEM supplemented with $10 \%$ FBS in triplicate. After $24 \mathrm{~h}$, the cells were incubated with $100 \mu \mathrm{L}$ of the extracts dilutions or medium only (negative control).

Cell Viability

Cell viability was assessed through 3-(4,5-Dimethylthiazol-2-yl)-2,5-diphenyltetrazolium bromide (MTT) Assay. The hPDLSCs were stimulated with the extracts for 24,48 , and $72 \mathrm{~h}$. The medium was renewed 
after $48 \mathrm{~h}$. The cell supernatant was replaced by $20 \mu \mathrm{L}$ of a $5 \mathrm{mg} / \mathrm{mL}$ solution of MTT in phosphate-buffered saline, followed by $180 \mu \mathrm{L}$ of $\alpha$-MEM with $10 \%$ FBS. Cells were incubated for $4 \mathrm{~h}$ and MTT solution was replaced by $100 \mu \mathrm{L}$ of dimethyl sulfoxide (Synth, Diadema, SP, Brazil). Optical density was determined using a plate reader (Synergy HT, Biotek, Instruments, Inc. Winooski, VT, USA) at the wavelength of $570 \mathrm{~nm}$.

\section{Statistical Analysis}

Normal data distribution was verified through the Shapiro-Wilk normality test and data were analyzed by two-way analysis of variance (Two-Way ANOVA) followed by Tukey's test $(\alpha=0.05)$. Data are presented as mean \pm standard deviation. All statistical analyses were performed using GraphPad Prism 7.00 (GraphPad Software, Inc., CA, US).

\section{Results}

The characterization of the hPDLSCs is shown in Figure 1. The results show high expression of mesenchymal stem cell surface markers CD-44 (100\%), CD-90 (95.7\%), and CD-146 (93.4\%) and low expression of CD-3 1 (6.69\%), CD-34 (7.99\%), OCT-4 (19.2\%) and SOX-2 (13.4\%). STRO-1 was $48.2 \%$.

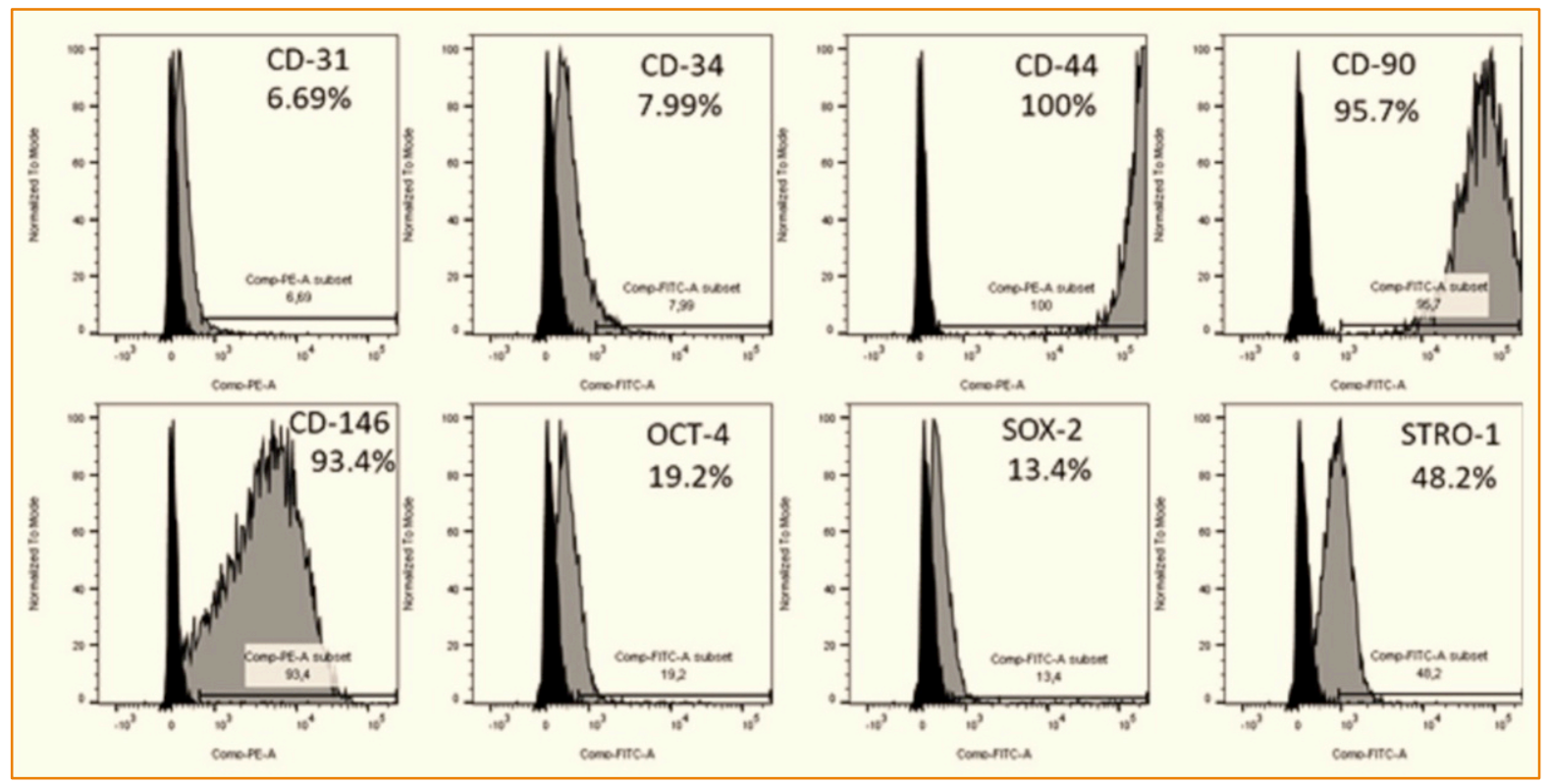

Figure 1. Characteristics of the hPDLSCs detected by flow cytometry. hPDLSCs stained with surface markers are shown as brown curves, and control hPDLSCs with no staining are shown as black curves.

Figure 2 show the cell viability according to MTT assay in SCAPs after 24 (A), 48 (B) and 72 (C) hours of exposure to different dilutions (1, 1:4 and 1:16) of the extracts of Biodentine, Bio-C Repair, Cimmo HD, MTA Repair HP and White MTA.

At $24 \mathrm{~h}$, pure extract of MTA Repair HP when pure and Biodentine 1:16 presented higher cell viability $(\mathrm{p}<0.0001)$. Compared to control, lower cell viability was found for pure extract of Cimmo HD $(\mathrm{p}<0.01)$, MTA Repair HP ${ }^{\circledR} 1: 4$ and 1:16 $(\mathrm{p}<0.05)$, and White MTA 1:16 $(\mathrm{p}<0.05)$.

In the $48 \mathrm{~h}$ period, pure extract of Bio-C Repair and MTA Repair HP presented higher cell viability than control $(\mathrm{p}<0.0001)$. On the other hand, lower cell viability was observed for pure extract of Cimmo HD $(\mathrm{p}<0.0001)$ and White MTA $(\mathrm{p}<0.05)$, Cimmo HD 1:4 $(\mathrm{p}<0.05)$ and MTA Repair HP ${ }^{\circledR} 1: 16(\mathrm{p}<0.05)$. 
At $72 \mathrm{~h}$ of stimulation, only the pure extract of MTA Repair HP led to higher cell proliferation compared to control $(\mathrm{p}<0.001)$. The cell viability of pure extract of Bio-C Repair, Cimmo HD and White MTA were lower than control group $(\mathrm{p}<0.0001)$. For the 1:4 dilution, Biodentine and Cimmo HD had lower cell proliferation than control $(\mathrm{p}<0.0001)$.

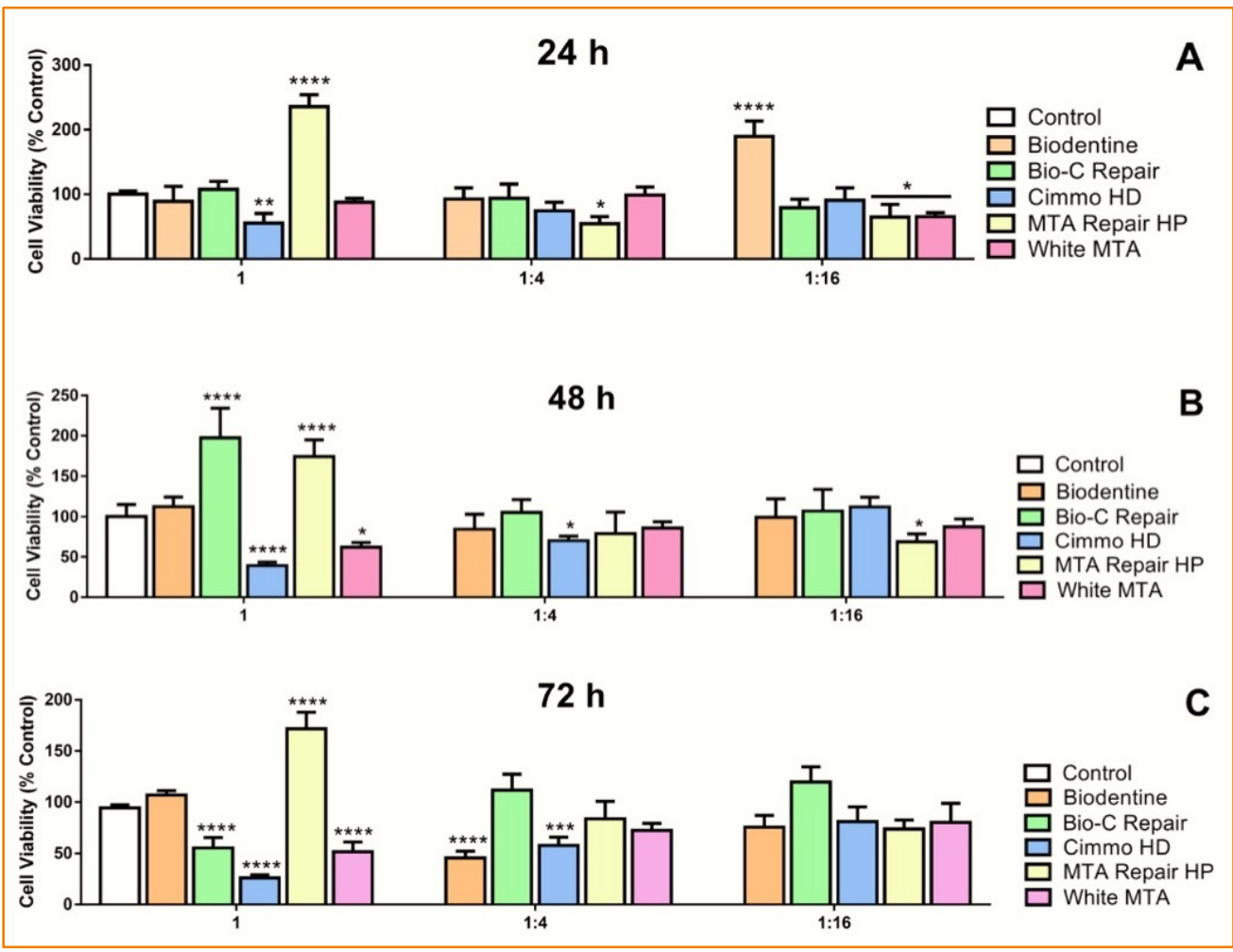

Statistically significant differences are indicated by $(*)$ when $\mathrm{p}<0.05,\left(*^{*}\right)$ when $\mathrm{p}<0.01$, (***) when $\mathrm{p}<0.001$ and (******) when $\mathrm{p}<0.0001$ compared to the control group. Two-Way ANOVA with Tukey test $(\alpha<0.05)$.

Figure 2. Cell viability according to MTT assay in SCAPs after 24 (A), 48 (B) and 72 (C) hours of exposure to pure (1), 1:4 and 1:18 dilutions of the extracts of Biodentine, Bio-C Repair, Cimmo HD, MTA Repair and White MTA. hPDLSCs incubated in culture medium alone served as the negative control. The results show mean and standard deviation of the experiments performed in triplicate.

\section{Discussion}

An ideal calcium silicate-based material must present low cytotoxicity. In this study, we evaluated the toxicity of Biodentine, Bio-C Repair, Cimmo HD, MTA Repair HD and White MTA on stem cells of the human periodontal ligament. The null hypothesis was rejected as the cements presented different toxicity profiles in the hPDLSCs. Overall, the results showed that Biodentine, Bio-C Repair HP and MTA Repair induced cell proliferation, whereas Cimmo HD and White MTA were mostly cytotoxic.

The endodontic treatment consists of the disinfection and filling the root canal with synthetic, inert or bioactive materials capable of inducing the formation of mineralized tissue and thus, contributing to tissue healing [19-21]. Interestingly, during endodontic procedures, despite the possibility of placing the bioactive cements in contact with stem cells, an influx of undifferentiated stem cells from the apical papilla and periradicular tissues into the root canal system may occur [22,23].

In this study, the cytotoxicity of the cements were evaluated in periodontal ligament stem cells, which the phenotypic characterization is in agreement with previous studies [24-26]. Several published studies have pointed to the use of these cells to assess the toxicity of new endodontic materials in vitro [11,17,27-31]. These 
cells reside around teeth, have a higher proliferation rate and possess the ability of multipotent differentiation such as osteogenesis, adipogenesis and chondrogenesis [27]. Furthermore, by working with cements extracts in different dilutions, a possible dose-response of the cements on the hPDLSCs could be inferred, as the cements release soluble components that may be diluted by surrounding tissue fluids in vivo [17,32,33].

Biodentine is a calcium silicate-based cement, synthesized to be used in direct contact with the periodontal ligament [27]. Previous studies have shown that Biodentine enhanced the proliferative activity of hPDLSCs [27,30]. This was also observed in our study in the first $24 \mathrm{~h}$. Higher concentrations $(20 \mathrm{mg} / \mathrm{mL})$ of Biodentine $^{\mathrm{TM}}$ were found to be more cytotoxic on PDLSCs. Lower concentration, however, increased the proliferation of hPDLSCs [27]. Thus, this corroborates our study, in which a dose-response regarding cell proliferation was observed.

In a study in which hPDLSCs were exposed to several dilutions of Bio-C Repair, similar cell viability was found for this cement compared to the control in $24 \mathrm{~h}$ [11]. This was also observed in this study. Interestingly, pure extract of Bio-C Repair in $48 \mathrm{~h}$ and Bio-C Repair at 1:4 and 1:16 dilutions presented higher cell viability compared to the control. Thus, the differences found might be attributed to the evaluated experimental periods. Furthermore, physicochemical analyses, including $\mathrm{pH}$ and ion release, are required to better explain our results.

In this in vitro cytotoxicity study, the cell viability was significantly increased for MTA Repair HP compared to control up to $72 \mathrm{~h}$. Corroborating our findings, studies have shown increased proliferation of human dental pulp stem cells (hDPSCs) [12] and hPDLSCs [34] in the presence of MTA Repair HP [12,28]. In hDPSCs, however, the cell proliferation was lower than Biodentine [12]. Controversially, in a report [35], this material was slightly cytotoxic and did not lead to the proliferation of hPDLSCs.

In this study, White MTA and Cimmo HD presented lower cell viability in all experimental periods. As observed in our study, the literature shows that White MTA was not able to induce cell proliferation in L929 fibroblast cell lines [15] and periodontal ligament fibroblasts [17]. To the best of our knowledge to date, there is no published report on the effect of Cimmo HD on stem cells. White MTA and Cimmo HD were found to present good performance in vivo [14,36,37]. Notably, the results of this in vitro study must be interpreted with caution given that variations in experimental procedures and conditions may produce conflicting results and the concentration of toxic substances may decrease by tissue fluids under clinical situations [31].

Besides supporting the literature on Biodentine and White MTA, to the best of our knowledge, this is the first study that has evaluated the biological properties Bio-C Repair, Cimmo HD and MTA Repair on human periodontal ligament stem cells. Thus, it helps to illuminate the properties of these materials. However, as limited evidence is currently available regarding to the outcomes of most of the calcium silicate-based assessed in this study, a broader in vitro experimental approach to clarify the biological and physicochemical properties of these materials, as well as the short and long-term assessment of their performance in vivo is necessary to better understand the behavior of these materials.

\section{Conclusion}

Biodentine, Bio-C Repair and MTA Repair HP were able to induce hPDLCs proliferation whereas Cimmo HD and White MTA were found to be mostly cytotoxic up to $72 \mathrm{~h}$.

\section{Authors' Contributions}




\begin{tabular}{|c|c|c|}
\hline MSP & https://orcid.org/0000-0002-4052-7208 & $\begin{array}{l}\text { Conceptualization, Investigation, Data Curation, Formal Analysis, Writing - Original Draft, } \\
\text { Writing - Review, Editing and Project Administration. }\end{array}$ \\
\hline TA & https://orcid.org/0000-0002-3377-725X & Investigation, Data Curation, Formal Analysis, Writing - Review and Editing. \\
\hline JGR & https://orcid.org/0000-0003-2761-8188 & Data Curation, Formal Analysis, Writing - Original Draft, Writing - Review and Editing. \\
\hline FNN & https://orcid.org/0000-0002-6595-9154 & Formal Analysis, Writing - Review and Editing and Project Supervision. \\
\hline CRS & https://orcid.org/0000-0002-5719-6505 & $\begin{array}{l}\text { Conceptualization, Data Curation, Formal Analysis, Writing - Review and Editing, Project } \\
\text { Administration and Supervision. }\end{array}$ \\
\hline
\end{tabular}

\section{Financial Support}

This study was supported by grants and scholarships from São Paulo Research Foundation (FAPESP) (processes 2016/13944-5 and 2017/23158-0), the National Council for Scientific and Technological Development (406923/2016-7) and Coordination for the Improvement of Higher Education Personnel (CAPES).

\section{Conflict of Interest}

The authors declare no conflicts of interest.

\section{Data Availability}

The data used to support the findings of this study can be made available upon request to the corresponding author.

\section{References}

[1] Torabinejad M, Parirokh M. Mineral trioxide aggregate and other bioactive endodontic cements: an updated overview - part II: other clinical applications and complications. Int Endod J 2018; 51(3):284-317. https://doi.org/10.1111/iej.12843

[2] Roberts HW, Toth JM, Berzins DW, Charlton DG. Mineral trioxide aggregate material use in endodontic treatment: a review of the literature. Dent Mater 2008; 24(2):149-64. https://doi.org/10.1016/j.dental.2007.04.007

[3] Parirokh M, Torabinejad M, Dummer P. Mineral trioxide aggregate and other bioactive endodontic cements: an updated overview-part I: vital pulp therapy. Int Endod J 2018; 51(2):177-205. https://doi.org/10.1111/iej.12841

[4] Możyńska J, Metlerski M, Lipski M, Nowicka A. Tooth discoloration induced by different calcium silicate-based cements: a systematic review of in vitro studies. J Endod 2017; 43(10):1593-601. https://doi.org/10.1016/j.joen.2017.04.002

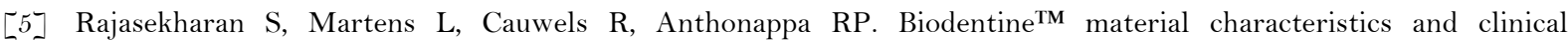
applications: a 3 year literature review and update. Eur Arch Paediatr Dent 2018; 19(1):1-22. https://doi.org/10.1007/s40368-018-0328-x

[6] Rajasekharan S, Martens LC, Cauwels RG, Verbeeck RM. Biodentine ${ }^{\text {TM }}$ material characteristics and clinical applications: a review of the literature. Eur Arch Paediatr Dent 2014; 15(3):147-58.

https://doi.org/10.1007/s40368-014-0114-3

[7] Camilleri J, Sorrentino F, Damidot D. Investigation of the hydration and bioactivity of radiopacified tricalcium silicate cement, Biodentine and MTA Angelus. Dent Mater 2013; 29(5):580-93. https://doi.org/10.1016/j.dental.2013.03.007

[8] Malkondu Ö, Kazandağ MK, Kazazoğlu E. A review on biodentine, a contemporary dentine replacement and repair material. Biomed Res Int 2014; 2014:160951. https://doi.org/10.1155/2014/160951

[9] Benetti F, Queiroz Í OA. cytotoxicity, biocompatibility and biomineralization of a new ready-for-use bioceramic repair material. Braz Dent J 2019; 30(4):325-32. https://doi.org/10.1590/0103-6440201902457

[10] Ghilotti J, Sanz JL, López-García S, Guerrero-Gironés J, Pecci-Lloret MP, Lozano A, et al. Comparative surface morphology, chemical composition, and cytocompatibility of Bio-C Repair, Biodentine, and ProRoot MTA on hDPCs. Materials 2020; 13(9):2189. https://doi.org/10.3390/ma13092189

[11] López-García S, Lozano A, García-Bernal D, Forner L, Llena C, Guerrero-Gironés J, et al. Biological effects of new hydraulic materials on human periodontal ligament stem cells. J Clin Med $2019 ; \quad 8(8): 1216$. https://doi.org/10.3390/jcm8081216

[12] Tomás-Catalá C, Collado-González M, García-Bernal D, Oñate-Sánchez R, Forner L, Llena C, et al. Comparative analysis of the biological effects of the endodontic bioactive cements MTA-Angelus, MTA Repair HP and NeoMTA Plus on human dental pulp stem cells. Int Endod J 2017; 50(Suppl 2):e63-e72. https://doi.org/10.1111/iej.12859

[13] Guimarães BM, Prati C, Duarte MAH, Bramante CM, Gandolfi MG. Physicochemical properties of calcium silicatebased formulations MTA Repair HP and MTA Vitalcem. J Appl Oral Sci 2018; 26:e2017115. https://doi.org/10.1590/1678-7757-2017-0115

[14] Moysés FV, Veiga DF, Pereira MJ, Dominguete MHL, Pazzini CA, Pereira ACJ, et al. Bioactive and biocompatible cement as a single element in pulpotomy of deciduous teeth: a randomized clinical trials. Rev Gaúch Odontol 2020; 68:e20200028. https://doi.org/10.1590/1981-863720200002820180081 
[15] Cintra LTA, Benetti F, de Azevedo Queiroz ÍO, de Araújo Lopes JM, de Oliveira SHP, Araújo GS, et al. Cytotoxicity, biocompatibility, and biomineralization of the new high-plasticity MTA material. J Endod 2017; 43(5):774-778. https://doi.org/10.1016/j.joen.2016.12.018

[16] Rovai ES, Ambrósio LMB, de França BN, de Oliveira LR, Gasparoni LM, Sipert CR. Protease-activated receptor type 1 activation enhances osteogenic activity in human periodontal ligament stem cells. Stem Cells Int 2019; 2019:6857386. https://doi.org/10.1155/2019/6857386

[17] Yoshino P, Nishiyama CK, Modena KCdS, Santos CF, Sipert CR. In vitro cytotoxicity of white MTA, MTA Fillapex ${ }^{\circledR}$ and Portland cement on human periodontal ligament fibroblasts. Braz Dent J 2013; 24(2):111-6. https://doi.org/10.1590/0103-6440201302115

[18] Karimjee C, Koka S, Rallis D, Gound T. Cellular toxicity of mineral trioxide aggregate mixed with an alternative delivery vehicle. Oral Surg Oral Med Oral Pathol Oral Radiol Endod 2006; 102(4):e115-20. https://doi.org/10.1016/j.tripleo.2005.12.020

[19] Rosa V. What and where are the stem cells for dentistry? Singapore Dent J 2013; 34(1):13-8. https://doi.org/10.1016/j.sdj.2013.11.003

[20] Sun HH, Jin T, Yu Q, Chen FM. Biological approaches toward dental pulp regeneration by tissue engineering. J Tissue Eng Regen Med 2011; 5(4):e1-16. https://doi.org/10.1002/term.369

[21] Horst OV, Chavez MG, Jheon AH, Desai T, Klein OD. Stem cell and biomaterials research in dental tissue engineering and regeneration. Dent Clin North Am 2012; 56(3):495-520. https://doi.org/10.1016/j.cden.2012.05.009

[22] Lovelace TW, Henry MA, Hargreaves KM, Diogenes A. Evaluation of the delivery of mesenchymal stem cells into the root canal space of necrotic immature teeth after clinical regenerative endodontic procedure. J Endod 2011; 37(2):133-8. https://doi.org/10.1016/j.joen.2010.10.009

[23] Althumairy RI, Teixeira FB, Diogenes A. Effect of dentin conditioning with intracanal medicaments on survival of stem cells of apical papilla. J Endod 2014; 4O(4):521-5. https://doi.org/10.1016/j.joen.2013.11.008

[24] Xu J, Wang W, Kapila Y, Lotz J, Kapila S. Multiple differentiation capacity of STRO-1+/CD146+ PDL mesenchymal progenitor cells. Stem cells Dev 2009; 18(3):487-96. https://doi.org/10.1089/scd.2008.0113

[25] Menicanin D, Mrozik KM, Wada N, Marino V, Shi S, Bartold PM, et al. Periodontal-ligament-derived stem cells exhibit the capacity for long-term survival, self-renewal, and regeneration of multiple tissue types in vivo. Stem cells Dev 2014; 23(9):1001-11. https://doi.org/10.1089/scd.2013.0490

[26] Alvarez R, Lee HL, Wang CY, Hong C. Characterization of the osteogenic potential of mesenchymal stem cells from human periodontal ligament based on cell surface markers. Int $J$ Oral Sci 2015; 7(4):213-9. https://doi.org/10.1038/ijos.2015.42

[27] Abuarqoub D, Aslam N, Jafar H, Abu Harfil Z, Awidi A. Biocompatibility of biodentine ${ }^{\mathrm{TM}}$ with periodontal ligament stem cells: In vitro study. Dent J 2020; 8(1):17. https://doi.org/10.3390/dj8010017

[28] Collado-González M, Tomás-Catalá CJ, Oñate-Sánchez RE, Moraleda JM, Rodríguez-Lozano FJ. Cytotoxicity of GuttaFlow Bioseal, GuttaFlow2, MTA Fillapex, and AH Plus on human periodontal ligament stem cells. J Endod 2017; 43(5):816-822. https://doi.org/10.1016/j.joen.2017.01.001

[29] Oh H, Kim E, Lee S. Comparison of biocompatibility of calcium silicate-based sealers and epoxy resin-based sealer on human periodontal ligament stem cells. Materials 2020; 13(22):5242. https://doi.org/10.3390/ma13225242

[30] Camps J, Jeanneau C, El Ayachi I, Laurent P, About I. Bioactivity of a calcium silicate-based endodontic cement (BioRoot RCS): interactions with human periodontal ligament cells in vitro. J Endod 2015; 41(9):1469-73. https://doi.org/10.1016/j.joen.2015.04.011

[31] Jing Y, Gong T, Duan C, Wang H, Zhang C, Neelakantan P. In vitro cytocompatibility and osteogenic potential of calcium silicate-based dental cements in a root canal-filling model. J Int Med Res 2020; 48(4):300060519894801. https://doi.org/10.1177/0300060519894801

[32] Ma J, Shen Y, Stojicic S, Haapasalo M. Biocompatibility of two novel root repair materials. J Endod 2011; 37(6):7938. https://doi.org/10.1016/j.joen.2011.02.029

[33] Bin CV, Valera MC, Camargo SE, Rabelo SB, Silva GO, Balducci I, et al. Cytotoxicity and genotoxicity of root canal sealers based on mineral trioxide aggregate. J Endod 2012; 38(4):495-500. https://doi.org/10.1016/j.joen.2011.11.003

[34] Collado-González M, López-García S, García-Bernal D, Oñate-Sánchez RE, Tomás-Catalá CJ, Moraleda JM, et al. Biological effects of acid-eroded MTA Repair HP and ProRoot MTA on human periodontal ligament stem cells. Clin Oral Investig 2019; 23(10):3915-3924. https://doi.org/10.1007/s00784-019-02822-2

[35] Rodríguez-Lozano FJ, López-García S, García-Bernal D, Pecci-Lloret MR, Guerrero-Gironés J, Pecci-Lloret MP, et al. In vitro effect of putty calcium silicate materials on human periodontal ligament stem cells. Applied Sci 2020; 10(1):325. https://doi.org/10.3390/app10010325

[36] Petrou MA, Alhamoui FA, Welk A, Altarabulsi MB, Alkilzy M, H Splieth C. A randomized clinical trial on the use of medical Portland cement, MTA and calcium hydroxide in indirect pulp treatment. Clin Oral Investig 2014; 18(5):1383-9. https://doi.org/10.1007/s00784-013-1107-z

[37] Awawdeh L, Al-Qudah A, Hamouri H, Chakra RJ. Outcomes of vital pulp therapy using mineral trioxide aggregate or biodentine: a prospective randomized clinical trial. J Endod 2018; 44(11):1603-9. https://doi.org/10.1016/j.joen.2018.08.004 